\title{
Radiometric Method for the Research on Geomechanical Parameters of Rocks
}

\author{
Michał Bonczyk, ${ }^{1}$ Małgorzata Wysocka, ${ }^{1}$ Mirosława Bukowska, ${ }^{1}$ Bogusław Michalik, ${ }^{1}$ \\ Stanisław Prusek, ${ }^{1}$ and Mariusz Wadas ${ }^{1}$
}

\begin{abstract}
Tests aimed to verify whether there is a correlation between the basic parameters characterizing the mechanical properties of rocks with the properties of ionizing radiation scattered by rocks were performed as part of the research. The positive correlation between the two examined properties would provide the basis for the development of a new method of rock testing using radiation sources or devices generating ionizing radiation. The method could be applied to carry out research in underground boreholes to determine the mechanical properties of the rock mass in situ. The study allowed the verification of the adopted assumptions for the proposed method. The verification was based on the correlation analysis of absorption coefficients of the ionizing radiation of rocks from the Upper Silesian Coal Basin with the results of the research on mechanical and physical properties.
\end{abstract}

Key words: Ionizing radiation, mechanical properties, linear absorption coefficient.

\section{Introduction}

The research methods used so far for the study of physical parameters of rocks require significant workload on the part of technical staff, and the obtained results are often burdened with an error resulting from a subjective interpretation of the analytical specialist (Bukowska 2012). Quick and accurate diagnosis of the mechanical properties of rocks has a direct impact on the increase in safety of the conducted mining operations. Proper evaluation of the selected parameters of rocks allows an optimal choice of the adopted mining techniques and making rational decisions regarding, for example, opening out of new areas of deposits.

Radiometric methods have been used in well logging for years. Geophysical well logging is

1 Central Mining Institute, Plac Gwarków 1, 40-166 Katowice, Poland. E-mail: mwysocka@gig.eu performed to determine the type of drilled rock and the depth of its occurrence on the basis of its physical properties. The most commonly used are: naturally occurring gamma radiation logging (PG), neutrongamma (PNG), and gamma-gamma logging (PGG) (Jarzyna 2002; Woźnicka et al. 2005; Jarzyna and Woźnicka 2006). The analysis of the recorded values enables to specify the lithological nature and some properties of the drilled rocks. The interpretation of the results is, therefore, indirect and often only indicative. Moreover, it is hindered by both the technical and natural phenomena (geological) modifying the properties of rocks.

One of the methods for determining the physical properties, including geomechanical ones, of rocks is to link them with the parameters describing the transmission and absorption of gamma radiation in rocks, e.g. the linear absorption coefficient $\mu$ ). To determine this value, a set of isotope sources and an appropriate detection system should be applied, e.g. using the method of high-resolution gamma-ray spectrometry (Conner et al. 1970; Bonczyk et al. 2015). On the basis of the measurement results of the absorption coefficient, e.g. density and/or porosity of the sea bottom sediments or lithologically varying rocks were determined (Weber et al. 1997; Bodwadkar and Reis 1994). Bielecki and his co-workers in the laboratory conditions, using computer microtomography by means of $\mathrm{X}$ radiation microbeam, studied the porosity of rocks (Bielecki et al. 2013). Another issue is the study of the protective properties of rocks and building materials (Akkurt et al. 2010; Bashter 1997; Mavi and Akkurt 2015). In recent years, studies were undertaken aimed to optimize determination of rock fragility parameter, which is a primary indicator of susceptibility of rocks to hydraulic fracturing, used in the first working of shale 
gas. For the selected patches of Miocene rocks, a good correlation between mineral and chemical composition with (photoelectric) absorption coefficient of gamma radiation measured in the laboratory conditions was found (Kowalska 2012).

Measurements of the absorption coefficient of 33 samples of sedimentary rocks accompanying coal seams, collected from 11 underground coal mines, were carried out as part of the work. It was examined whether there is a functional relation between the selected mechanical parameters of rocks-uniaxial compressive strength $R_{\mathrm{c}}$ and bulk density $\rho$-an absorption coefficient of gamma radiation. The aim of the analyses was to verify the thesis of the possibility of using gamma spectrometry to support the evaluation of the geomechanical properties of sedimentary rocks accompanying hard coal deposits.

\section{Materials and Methods}

The study involved 33 samples of Carboniferous sedimentary rocks, i.e. claystones, mudstones and sandstones from 11 hard coal mines. The samples represent lithostratigraphic units of productive Carboniferous of the Upper Silesian Coal Basin: Westphalian A and the Upper Silesian Sandstone Series Namurian B + C. Claystones and coarse clastic Carboniferous rocks which have a different position in the lithostratigraphic profile differ in their petrographic structure, mineral composition and thus differ regarding the geomechanical properties (Bukowska 2012; Bogusz and Bukowska 2015). The studied rocks include claystones (20 samples), sandstones of different grain size (10 samples) and mudstones ( 3 samples). A total of 33 samples in a cylindrical shape with a diameter of $50 \mathrm{~mm}$ and a height of $50 \mathrm{~mm}$ or cube with a side of $50 \mathrm{~mm}$ were tested. The samples were tested for uniaxial compression, consisting in the loading of rock with compressive force evenly growing, until reaching the force destructive for the sample. A machine with a servomechanism was used for testing and the crosshead speed was $0.005 \mathrm{~mm} / \mathrm{s}$. A load was imposed on samples perpendicular to the stratification. The stress values obtained provide the basis for the calculation of uniaxial compressive strength, expressed in megapascals [MPa]. The values of uniaxial compression $R_{\mathrm{c}}$ are calculated on the basis of the results obtained for at least 5 samples (Bukowska 2012). The tests were performed in accordance with the recommendations of the International Society of Rock Mechanics (ISRM) (Ulusey and Hudson 2007).

Density $\rho$, expressed in grams per cubic centimetre $\left[\mathrm{g} / \mathrm{cm}^{3}\right]$, was determined in accordance with the procedure PN-82/G-045. Density value is calculated on the basis of the results of the study of at least 3 samples.

The linear absorption coefficient was determined using the measurement system composed of the sources of gamma radiation ${ }^{137} \mathrm{Cs}(662 \mathrm{keV}),{ }^{210} \mathrm{~Pb}$ (47 keV), germanium detector of broad energy type (BEGe) and MCA multi-channel analyser to analyse amplitude. The linear absorption coefficient was calculated using the Lambert's law, according to the equation:

$$
I=I_{0} e^{-\mu x},
$$

where $\mu$ is the linear absorption coefficient $\left[\mathrm{cm}^{-1}\right], I_{0}$ is the primary intensity of gamma radiation beam, $I$ is the intensity of a gamma radiation beam after passing through an absorber with a thickness of $x$ and $x$ is the absorber thickness (measured rock sample) [cm].

Rewriting the Eq. (1) in a logarithmic form and ordering the terms, the following is obtained:

$$
\mu=\frac{1}{x} \ln \left(\frac{I_{0}}{I}\right) .
$$

The radiation source was in a lead collimator approx. $5 \mathrm{~cm}$ above the window of the detector. Rock samples were placed in the space between the source and the detector. Rock samples had the shape of a flat cylinder with a diameter of $90 \mathrm{~mm}$ and a height of $25 \mathrm{~mm}$.

\section{Results of Research and Discussion}

Linear absorption coefficient was determined for the studied rocks using gamma photons of energy of $46.5 \mathrm{keV}$ and 661.6 obtained from two radiation sources: ${ }^{210} \mathrm{~Pb}$ and ${ }^{137} \mathrm{Cs}$, respectively. Coefficient of uniaxial compressive strength $R_{\mathrm{c}}$ and the density $\rho$ were determined in the laboratory conditions for all 
the tested samples. The value of the parameters which characterize the mechanical properties of the studied rocks is in the range from 25.0 to $93.8 \mathrm{MPa}$ in the case of the coefficient $R_{\mathrm{c}}$, and from 2.32 to $2.83 \mathrm{~g} /$ $\mathrm{cm}^{3}$ for density. The measured values do not deviate from the ranges and mean values of the discussed coefficients of Carboniferous rocks, provided by Bukowska (Bukowska 2012). The absorption coefficients were calculated for all samples, for both radiation sources used.

Table 1 presents the results of tests and calculations.

The determined values of the linear absorption coefficient range from 0.166 to $0.250 \mathrm{~cm}^{-1}$ for the energy of $662 \mathrm{keV}$, and from 0.337 to $0.973 \mathrm{~cm}^{-1}$ for the energy of $47 \mathrm{keV}$. The highest values of the absorption coefficient have been observed for grey claystone (respectively, 0.250 and $2.480 \mathrm{~cm}^{-1}$ ). The lowest values of the absorption coefficient were recorded for claystone $\left(662 \mathrm{keV}: 0.166 \mathrm{~cm}^{-1}\right)$ and for fine grey sandstone (47 keV: $0.754 \mathrm{~cm}^{-1}$ ).

It has been verified whether there is a relationship between the measured values of the linear absorption coefficient and uniaxial compression strength $R_{\mathrm{c}}$.

For the entire population of 33 tested samples, there was no relationship found between the analysed parameters-Figs. 1 and 2.

In view of the fact that there was no relation confirmed between $R_{\mathrm{c}}$ and $\mu$ both for the energy 47 and $662 \mathrm{keV}$, all samples were grouped according to the determined $R_{\mathrm{c}}$ into 4 categories. The basis for the division was the regional classification of uniaxial compression strength of gangue from the Upper Silesian Coal Basin by Bukowska (Bukowska 2012), which was extended to a group of " $R_{\mathrm{c}}>80 \mathrm{MPa}$ ". All samples (33) were grouped according to these classes and the mean $\mu$ was calculated for both types

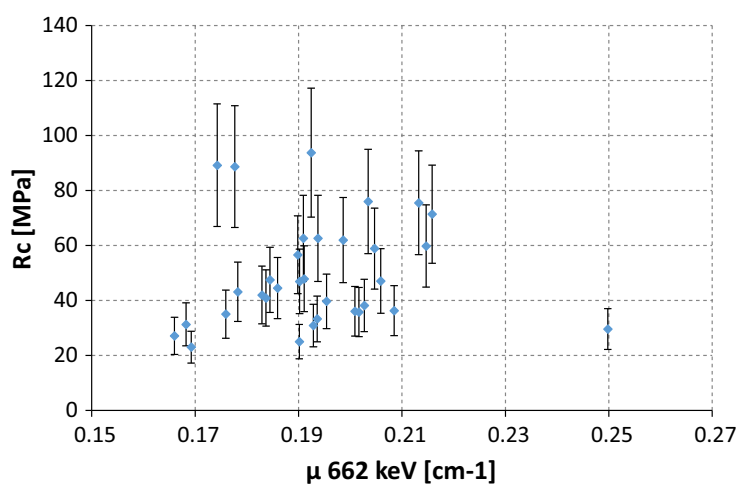

Figure 1

The relationship between the determined coefficient $\mu$ for the energy of $662 \mathrm{keV}$ and uniaxial compressive strength $\left(R_{\mathrm{c}}\right)$

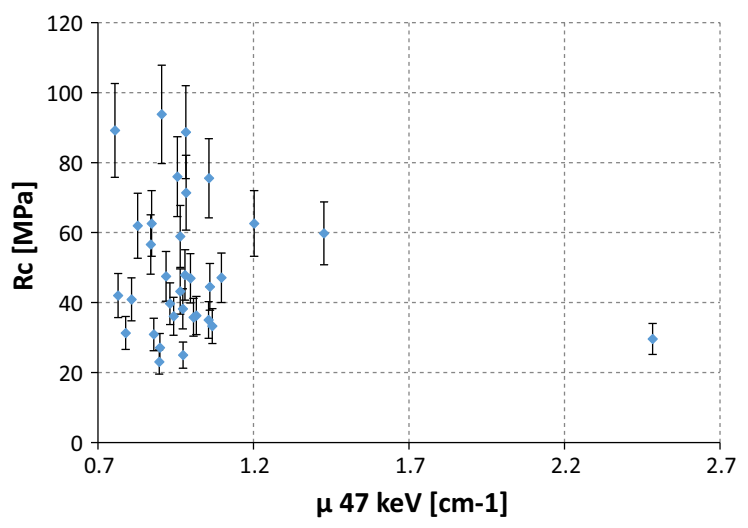

Figure 2

The relationship between the determined coefficient $\mu$ for energy $47 \mathrm{keV}$, and the uniaxial compressive strength $\left(R_{\mathrm{c}}\right)$

Table 1

Summary of the results of mechanical parameters' measurements of $R_{c}$ and $\rho$ and the absorption coefficient $\mu$ for energy 662 and 47 keV

\begin{tabular}{|c|c|c|c|c|c|}
\hline Rock & No. of samples & $\begin{array}{l}R_{\mathrm{c}}[\mathrm{MPa}] \\
\text { Range } \\
\text { Mean }\end{array}$ & $\begin{array}{l}\rho\left[\mathrm{g} / \mathrm{cm}^{3}\right] \\
\text { Range } \\
\text { Mean }\end{array}$ & $\begin{array}{l}\mu\left[\mathrm{cm}^{-1}\right] 662 \mathrm{keV} \\
\text { Range } \\
\text { Mean }\end{array}$ & $\begin{array}{l}\mu\left[\mathrm{cm}^{-1}\right] 47 \mathrm{keV} \\
\text { Range } \\
\text { Mean }\end{array}$ \\
\hline Sandstone & 10 & $\begin{array}{l}31.3-93.8 \\
63.1\end{array}$ & $\begin{array}{l}2.32-2.64 \\
2.43\end{array}$ & $\begin{array}{l}0.168-0.199 \\
0.184\end{array}$ & $\begin{array}{l}0.754-0.982 \\
0.841\end{array}$ \\
\hline Mudstone & 3 & $\begin{array}{l}36.3-76.0 \\
62.6\end{array}$ & $\begin{array}{l}2.58-2.64 \\
2.61\end{array}$ & $\begin{array}{l}0.204-0.213 \\
0.208\end{array}$ & $\begin{array}{l}0.955-1.057 \\
1.009\end{array}$ \\
\hline Claystone & 20 & $\begin{array}{l}25.0-71.4 \\
41.5\end{array}$ & $\begin{array}{l}2.51-2.83 \\
2.71\end{array}$ & $\begin{array}{l}0.166-0.250 \\
0.195\end{array}$ & $\begin{array}{l}0.880-2.480 \\
1.080\end{array}$ \\
\hline All samples & 33 & $\begin{array}{l}25.0-93.8 \\
49.7\end{array}$ & $\begin{array}{l}2.32-2.83 \\
2.56\end{array}$ & $\begin{array}{l}0.166-0.250 \\
0.194\end{array}$ & $\begin{array}{l}0.754-2.480 \\
0.394\end{array}$ \\
\hline
\end{tabular}


of energy in each group (Table 2). In the studied population of rocks, there were no samples that could be classified into the group " $R_{\mathrm{c}}<20 \mathrm{MPa"}$ " The obtained relations are shown in diagrams (Figs. 3, 4). The mean $\mu$ was marked in each group, together with the standard deviation, which is a measure of the dispersion of $\mu$ in each group.

It is noted that for the energy of $47 \mathrm{keV}$, coefficient $\mu$ is a weakly decreasing function $R_{\mathrm{c}}$-almost identical ranges of variation $\mu$ exist in each of the groups $R_{\mathrm{c}}$. A

Table 2

Distribution of the studied population of samples into the strength classes

\begin{tabular}{lcll}
\hline Strength class [MPa] & No. of samples & $\mu(47 \mathrm{keV})$ & $\mu(662 \mathrm{keV})$ \\
\hline$<20$ & 0 & - & - \\
$20-40$ & 13 & 1.070 & 0.193 \\
$40-60$ & 11 & 0.986 & 0.192 \\
$60-80$ & 6 & 0.983 & 0.203 \\
$>80$ & 3 & 0.881 & 0.181 \\
\hline
\end{tabular}

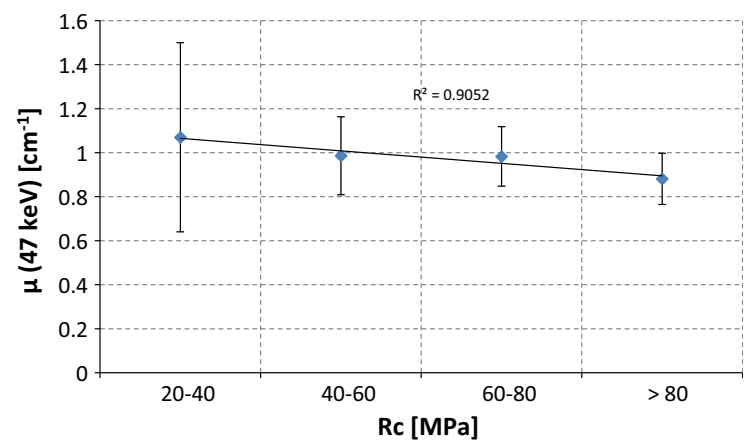

Figure 3

Mean $\mu(47 \mathrm{keV})$ for the four classes of strength for gangue from the USCB

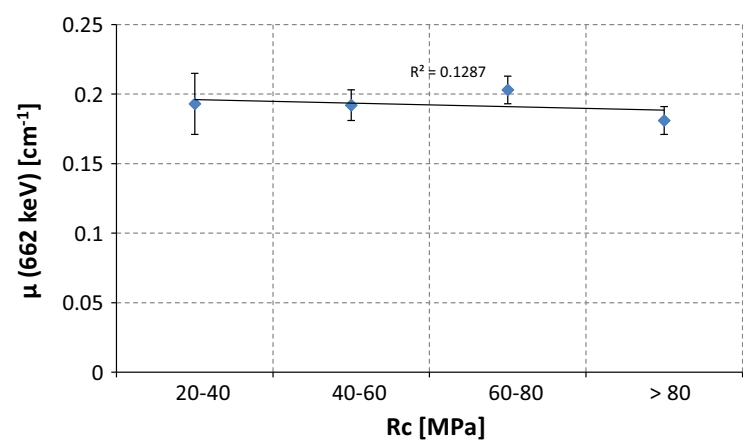

Figure 4

Mean $\mu(662 \mathrm{keV})$ for four strength classes of gangue from the Upper Silesian Coal Basin similar relationship between the resistance to uniaxial compression and the absorption coefficient $\mu$ is observed for the energy of $662 \mathrm{keV}$. The very low coefficient of determination $R^{2}$ should be paid special attention to, as it indicates which part of the variability of response variable (in this case $\mu$ ) was explained by the accepted model. Due to the relatively high variability of both $\mu$ and $R_{\mathrm{c}}$ in each group, the usefulness of the adopted linear model is low.

It was noted, however, that there is a relationship between the examined parameters for a group of claystone representing layers of the Westphalian A. The relationship between the studied parameters is presented in Figs. 5 and 6. The compressive strength of this group of claystones varies from 23 to $71 \mathrm{MPa}$, and the coefficient $\mu$ from 0.166 to $0.250 \mathrm{~cm}^{-1}$ for the energy of $662 \mathrm{keV}$ and from 0.880 to $2.480 \mathrm{~cm}^{-1}$ for the energy of $47 \mathrm{keV}$.

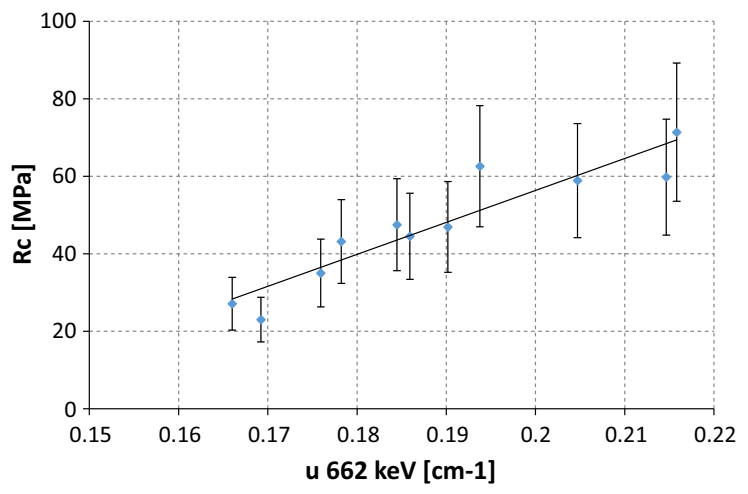

Figure 5

Dependence of $\mu(662 \mathrm{keV})$ on $R_{\mathrm{c}}$ for a group of claystone

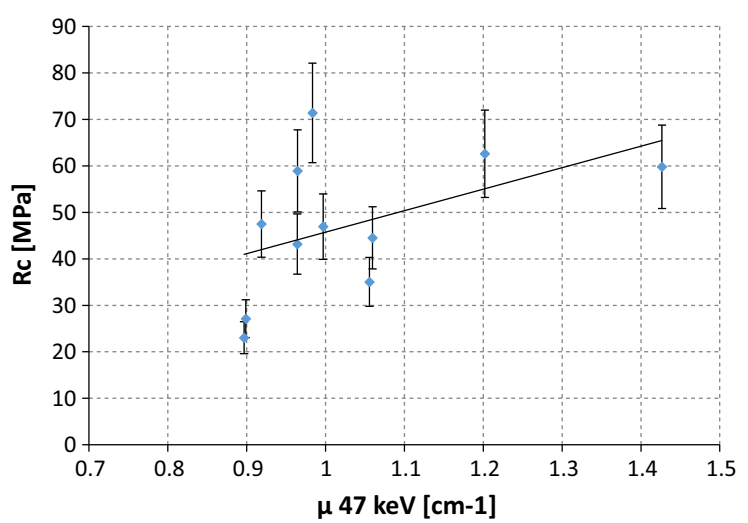

Figure 6

Dependence of $\mu$ (47 keV) on $R_{\mathrm{c}}$ for a group of claystone 
A similar relationship was observed for sandstone representing Namurian B $+\mathrm{C}$. The majority of samples in the studied group of sandstone, since 8 out of 10 samples, were fine-grained sandstones. Dependencies between the studied parameters for a group of sandstone are shown in Figs. 7 and 8.

The absorption of gamma rays in matter depends primarily on two parameters-the effective atomic number of the penetrated matter and the radiation energy. Figure 9 shows the absorption coefficients as a function of the radiation energy determined by means of the model XCOM (Berger 1961). For the modelling purposes, the averaging chemical composition of sandstone and claystone was adopted (Blewski and Parachoniak 1974). Since the density of the studied rock samples was characterized by rather high variability, the bulk density of $2.56 \mathrm{~g} / \mathrm{cm}^{3}$ was adopted in the model.

The values of absorption coefficients obtained in the modelling confirm the correctness of the results

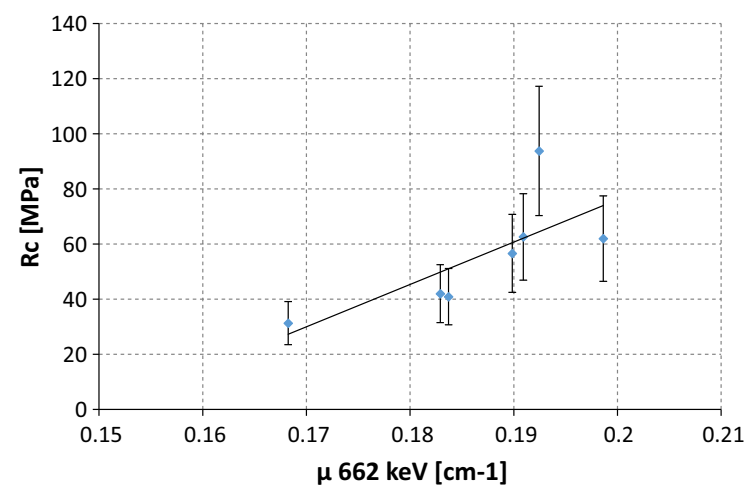

Figure 7

Dependence of $\mu(662 \mathrm{keV})$ on $R_{\mathrm{c}}$ for a group of sandstone

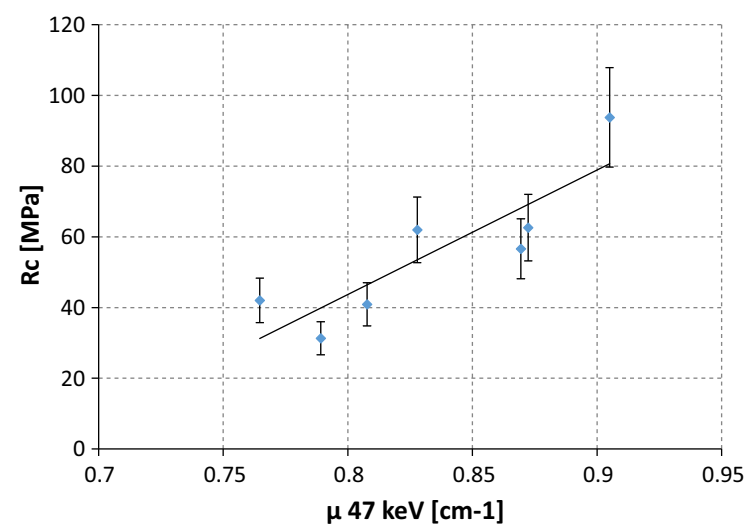

Figure 8

Dependence of $\mu(47 \mathrm{keV})$ on $R_{\mathrm{c}}$ for a group of sandstone obtained by means of the experimental method. The model has also demonstrated that the absorption of the radiation energy of 47 and $662 \mathrm{keV}$ strongly depends on even the slightest admixture of heavy elements (of a large atomic number) and is less dependent on the rock density. The obtained dependence of the radiation absorption on rock's density for a group of claystones is shown in Fig. 10.

An addition to the experiment should be a study of the absorption coefficient with the use of sources with different radiation energy, e.g. $60 \mathrm{keV}\left({ }^{241} \mathrm{Am}\right)$

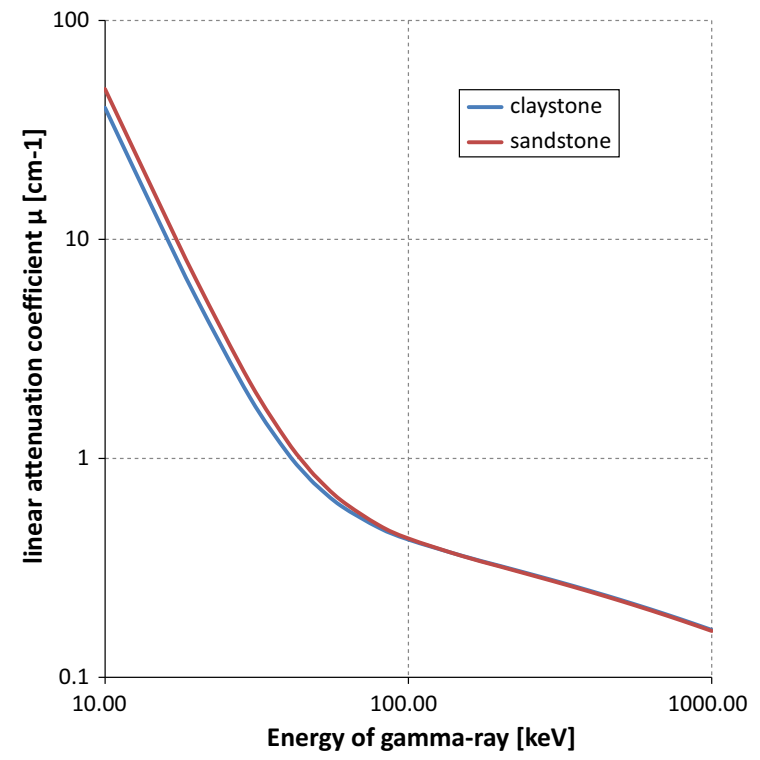

Figure 9

The dependence of the radiation absorption on energy for the two types of rocks (sandstone and claystone), determined by model $\mathrm{XCOM}$

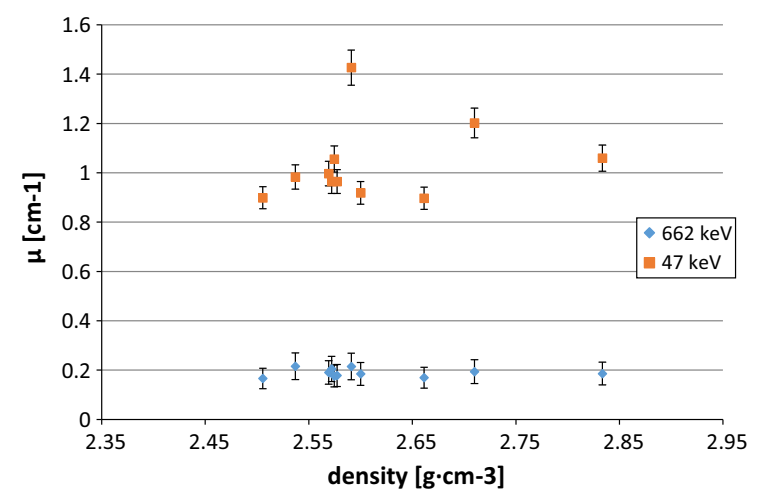

Figure 10

The dependence of the radiation absorption on rock's density for a group of claystones 
and a study of the spectrum of backscattered radiation $\left(\theta=180^{\circ}\right)$.

Analysis of the relationship between the selected strength parameters of the rock mass (uniaxial compressive strength) and the coefficient of ionizing radiation absorption shows that only for certain groups of rocks there is a correlation between them. The parameters determining the value of the linear absorption coefficient are mineralogical and chemical composition of the studied rocks. The changing conditions of sedimentation in certain periods of coal deposits formation affected the properties of both coal and rocks accompanying them. The measurements of the absorption coefficient of ionizing radiation enable to specify changes in the chemical and mineralogical composition of the studied rocks, namely the presence of interlayers and interbeds containing mineral inclusions.

\section{Summary and Conclusions}

Basic parameters characterizing the mechanical properties of rocks $R_{\mathrm{c}}$, density and linear absorption coefficients of gamma radiation for the energy of $47 \mathrm{keV}-{ }^{210} \mathrm{~Pb}$ and $662 \mathrm{keV}-{ }^{137} \mathrm{Cs}$ were measured as part of the work.

No correlation was found between the determined coefficients of absorption and resistance to uniaxial compression $R_{\mathrm{c}}$ for the measured rock samples; however, certain dependencies can be observed for certain groups of rocks separated with regard to their lithology (rock type).

The method allows the detection of discontinuities of the chemical composition of the studied rocks - the presence of interlayers, interbeds and mineral inclusions, e.g. of iron compounds.

The method can be considered as a supplement to previously used methods such as the penetrometric method and laboratory method.

\section{Acknowledgments}

This work was supported by Polish Ministry of Science and Higher Education within the statutory activity of the Central Mining Institute, contract number 11160555-370 in the period 4.01.201531.12.2015.

Open Access This article is distributed under the terms of the Creative Commons Attribution 4.0 International License (http:// creativecommons.org/licenses/by/4.0/), which permits unrestricted use, distribution, and reproduction in any medium, provided you give appropriate credit to the original author(s) and the source, provide a link to the Creative Commons license, and indicate if changes were made.

\section{REFERENCES}

Akkurt, I., Akyildirim, H., Mavi, B., Kilincarslan, S., \& Basyigit, C. (2010). Radiation shielding measurement of the concrete containing zeolite. Radiation Measurements, 45, 827-830.

Bashter, I. (1997). Calculation of radiation attenuation coefficients for shielding concretes. Annals of Nuclear Energy, 24(17), 1389-1401.

Berger, R. T. (1961). The X- or gamma-ray energy absorption or transfer coefficient: tabulations and discussion. Radiation Research, 15(1), 1-29.

Bielecki, J., Jarzyna, J., Bożek, S., Lekki, J., Stachura, Z., \& Kwiatek, W. M. (2013). Computed microtomography and numerical study of porous rock samples. Radiation Physics and Chemistry, 93, 59-66.

Bodwadkar, S. V., \& Reis, J. C. (1994). Porosity measurements of core samples using gamma-ray attenuation. Nuclear Geophysics, 8(1), 61-78.

Bogusz, A., \& Bukowska, M. (2015). Stress-strain characteristics as a source of information on the destruction of rocks under the influence of load. Journal of Sustainable Mining, 14(1), 76-82.

Bolewski, A., \& Parachoniak, B. (1974). Petrography, petrografia, in polish. Warsaw: Wydawnictwa Geologiczne.

Bonczyk, M., Michalik, B., \& Chmielewska, I. (2015). The selfabsorption correction factors for ${ }^{210} \mathrm{~Pb}$ concentration in mining waste and influence on environmental radiation risk assessment. Isotopes Environment Health Studies, 51(5), 1-7.

Bukowska, M. (2012). Rock mass susceptibility to bumps-geological and geomechanical test methods, Sktonność górotworu do tapań-geologiczne i geomechaniczne metody badań, in Polish. Katowice: Central Mining Institute.

Conner, A. L., Atwater, H. F., Plassmann, E. H., \& McCrary, J. H. (1970). Gamma-ray attenuation-coefficient measurements. Physical Review A, 1, 539.

Jarzyna, J. (2002). Updated geophysical measurements in exploratory boreholes (Nowoczesne pomiary geofizyczne w otworach badawczych, in Polish). Publications of the Polish Geological Institute, 50(2), 165-166.

Jarzyna, J., \& Woźnicka, U. (2006). Correctness of the comprehensive interpretation of well logs regarding to geological conditions and calculation methods. Proceedings of Near Surface 2006-12th EAGE European Meeting of Environmental and Engineering Geophysics, Helsinki, Finland. doi:10.3997/22144609.201402652.

Kowalska, S. (2012). The evaluation of the brittleness of the clastic rocks on the basis of their mineralogical and chemical composition and the photoelectric mass attenuation coefficient Pe, (Wyznaczanie kruchości skał na podstawie analizy składu 
mineralnego i chemicznego skał oraz fotoelektrycznego współczynnika absorpcji promieniowania gamma) in Polish. Scientific Works of the Oil and Gas Institute, 182, 567-571.

Mavi, B., \& Akkurt, I. (2015). Investigation of radiation absorption properties of some India granites. Acta Physica Polonica A, 128((2-B)), 370-371.

Ulusey, R., \& Hudson, J. A. (Eds.). (2007). The complete IRSM suggested methods for rock characterization, testing and mon itoring: 1974-2006. Ankara: Turkey Commission on Testing Methods ISRM.
Weber, M. E., Niessen, F., Kuhn, G., \& Wiedicke, M. (1997). Calibration and application of marine sedimentary physical properties using a multi-sensor core logger. Marine Geology, 136(3-4), 151-172.

Woźnicka, U., Jarzyna, J., \& Krynicka, E. (2005). Evaluation of uncertainty of the comprehensive interpretation of borehole logs by the multiple re-run statistical method. Applied Radiation Isotopes, 62, 817-827.

(Received June 28, 2016, revised August 31, 2016, accepted September 12, 2016, Published online September 21, 2016) 